\title{
Oral Histories of a Layered Landscape: The Rushworth Oral History Project
}

\author{
Keir Reeves, E. Rebecca SANDeRs And GoRdon Chisholm
}

PUBLIC HISTORY REVIEW, VOL 14, 2007, PP114-27

W hile the central Victorian town of Rushworth is situated in a remote location it has a dynamic past. Today many historical layers can be observed in the remnant cultural landscape of the former mining town and also throughout the box and ironbark forest that surrounds it on all sides. These layers include Indigenous life in the forest, European exploration and settlement, the discovery of gold, Chinese market gardening, the charcoal and eucalyptus industry and timber production. The popular history of locals also holds many community memories particularly about use of the forest up to and including the present day. By considering historical landscape in conjunction with local oral histories we argue that the history of the town and the forest can be understood as a cultural landscape. ${ }^{1}$ In doing so we suggest that 'natural' landscapes are 'cultural' in the sense that 'landscapes' are mental constructs, as are notions of significance.

According to Joseph Amato, 'local history satisfies an innate human desire to be connected to a place.' ${ }^{2}$ These yearnings can be recognised as part of a broader need to define and control identity. In the town of Rushworth, located in Central Victoria roughly halfway between Murchison and Bendigo, the longing of the residents to manage and control the identity of the township was observed during the recently conducted Rushworth Oral History Project. ${ }^{3}$

For over fifty years, the identity of Rushworth has been based on its economic dependence on forest related industries - principally logging and eucalyptus distillation and on its history of gold mining. This identity as a forestry and gold mining town has recently come under pressure due to the cessation of logging in the box and ironbark forests surrounding it. In light of this, the Forest Stewardship of the Victorian Department of Sustainability and the Environment (DSE) commissioned the Rushworth Oral History Project. The objective of the project was to record stories of a way of life that was no longer taking place, but the physical evidence of which was still apparent in the landscape surrounding the town. It was hoped that the project would encourage the local 
community to consider alternate uses of the box and ironbark forests that surrounded the town, including the idea that they could be used as a historical resource.

The project was funded by the DSE which manage the forests around Rushworth. The department recognised that the forest and the employment it supplied had created much of the town's identity and also acknowledged a strongly felt desire by members of the community to record their stories. ${ }^{4}$ The purpose of conducting the oral history interviews was two-fold. Primarily, the project was seen as an opportunity for the locals of Rushworth to discuss their association with the forest in the context of the changing usage designated by Parks Victoria and the land management policies implemented by the DSE. ${ }^{5}$ It was hoped that the project would highlight local understandings of the forest and its role in regional histories. ${ }^{6}$

As research proceeded the need to place the forestry history within broader cultural landscapes became apparent. The authors recognised that historical and geographical spaces were not 'the unproblematic category that is commonly assumed. Rather, spatial structures are related in subtle but significantly constitutive ways to social relations, manifesting as they do relations of power in society'.

It is the major theoretical contention of this article that these structures ought to be conceptualised as an archaeology of historical landscapes - landscapes that are both broad historical narratives and actual places.

As a town, Rushworth is embedded in its physical, cultural and historical landscapes. ${ }^{8}$ It is a place defined by rich historical layers: Indigenous peoples inhabited the area for an extensive time prior to European settlement which saw periods of pastoralism, gold seeking and, later, timber harvesting and eucalyptus distilling. Although the gold rushes have long since passed and logging is now severely curtailed, due to state government forestry policies enacted in the late 1990s, these industries continue to define much of the character and attitudes of the Rushworth community. This situation is more than that of a town defining itself through the myth and legend of its frontier history. Rather, the question of identity continues to inform debates over the future direction of the town. This is particularly demonstrated through the complex understandings of what the 'closing' of the forest meant in regard to Rushworth's ongoing identity as a timber town.

The formal end of the timber industry in the Rushworth region in part determined present day historical understandings of the town and its hinterland area: the forest had only been closed to ongoing logging and associated activities with access to it now being determined by new state and national park land management policies. ${ }^{9}$ Thus, an examination of the historical layers of the town and its region provides a solid foundation for the town to envisage its future direction. For the authors, such an examination took the form of the Rushworth Oral History Project. 


\section{IDENTIFYING THE LAYERS OF THE PAST}

Despite the fact that mining and forestry no longer dominate the local economy of the region, they continue to significantly define local community identity. It was therefore crucial to record and chronicle the stories of the community, especially of the individual lives of former forest workers as they experienced a period of significant change. The project placed the timber industry in the wider context of other concurrent patterns of life in the township.

In canvassing a wide section of the community, connections between the foresters and others in the community formed one of the most obvious landscapes and forestry remained the major theme throughout the interviews. Walking in the forest near the Balaclava mine, the immature trees and the weathered, sawn-off trunks were visual clues to the historical landscapes. However, the connections that crisscrossed this landscape were not the only ones we came upon. Complementing the 'horizontal' associations were the 'vertical' connections that stretched between present-day life in Rushworth and the historical landscapes of its past. Thus, the project began to emerge as a kind of archaeological investigation of the layered historical landscapes of Rushworth. That is, by situating the outcomes of research in the physical landscapes the authors began to envisage a typology of the oral histories, the people interviewed and the places recounted.

There were a number of landscapes that appeared quite consistently throughout the interviews. These included: present forestry practices and environmental uses of the forest; the war years and prisoner of war (POW) camps; the Great Depression and the presence of itinerant workers throughout the district; the gold era of both the original gold rush and that of the late 1800s; the settlement of the district and the pastoral life that continues through to the present; and, more remotely and haphazardly, the contact between a European settler society and the Indigenous people of the region. This last landscape evoked other hidden histories, including those of the Chinese gold miners and women of the gold rush period. There was a notable absence of both these populations in the recorded interviews.

While the project primarily focussed on obtaining the history and stories of the region at a local level, it also aimed to consider the relationship between the cultural and social history and the streetscapes and bushscapes of Rushworth and the surrounding forests. It was felt that the human story of the region was best understood and interpreted not only through personal histories but also by surveying the mining, timber and natural landscapes. This understanding and interpreting is to an extent a conjuring act by the investigators as well as by those interviewed. The landscape is something observed in which the human imagination invokes an impression of what was once on the surface. ${ }^{10}$ 


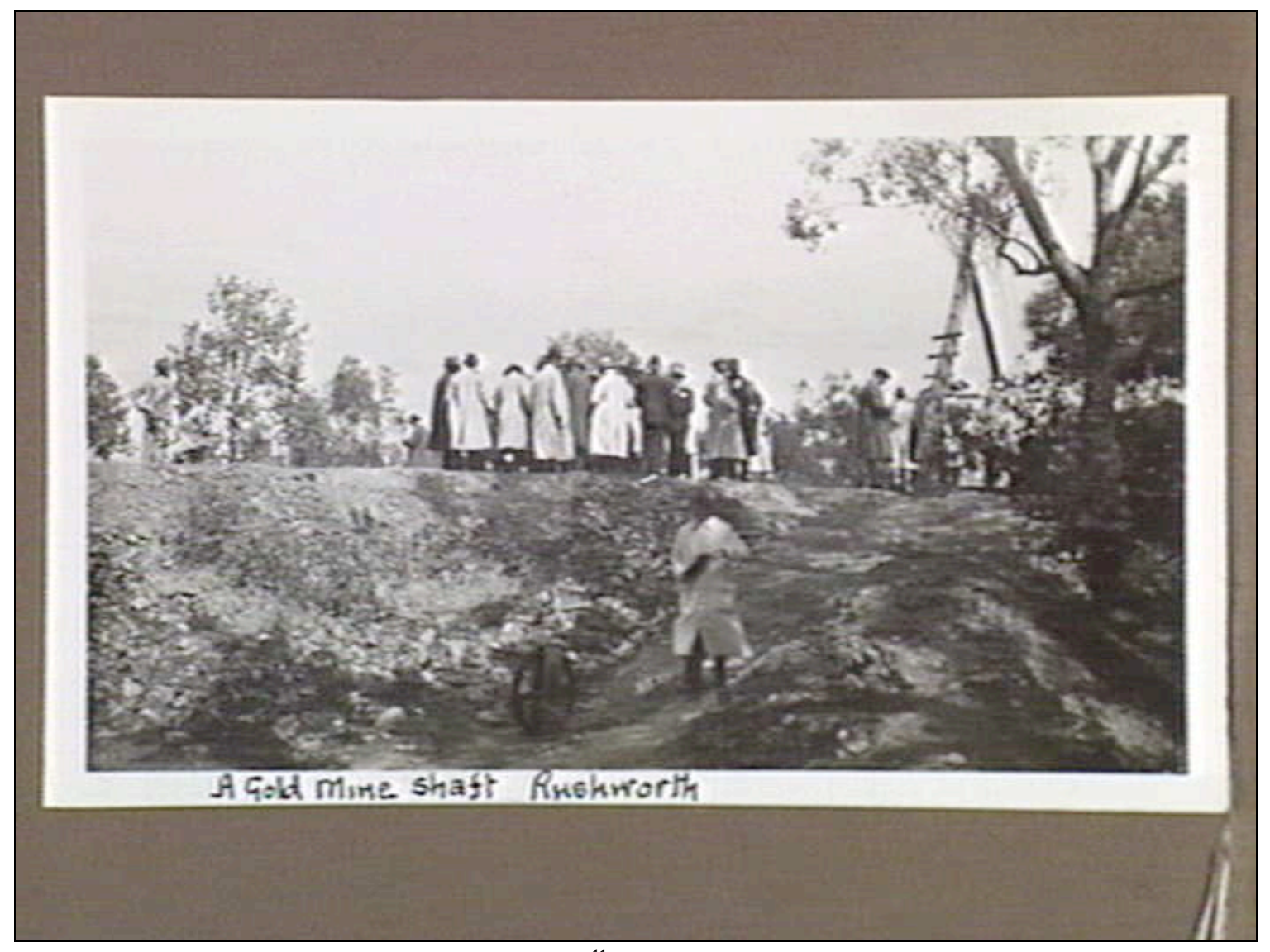

Looking for the historical layer: A gold mine shaft in $1923^{11}$

Moreover, the investigation interpreted this surface as a permeable boundary whose porous nature is probed by archaeological investigation of cultural landscapes. The methodology highlights the manner in which the physical landscape is overlaid with numerous forms of understanding, 'not... defined by the historical event but by the material elements which go to make up the landscape itself. ${ }^{, 13}$ In this respect the methodology reinforces the need to consider the oral history of the town in conjunction with the remnant landscapes of the region. It became apparent that Rushworth and its forests are best understood as an evolving cultural landscape which continues to define the town's identity up to the present day.

\section{Oral History Methodology}

Oral history is a useful method of collecting information, especially when written records are few or lack the personal views, feelings and thoughts that a recorded interview can provide. It enables researchers to obtain an impression of the way subjects make sense out of events in their own lives'. ${ }^{14}$ Interviews were conducted over a period of six 


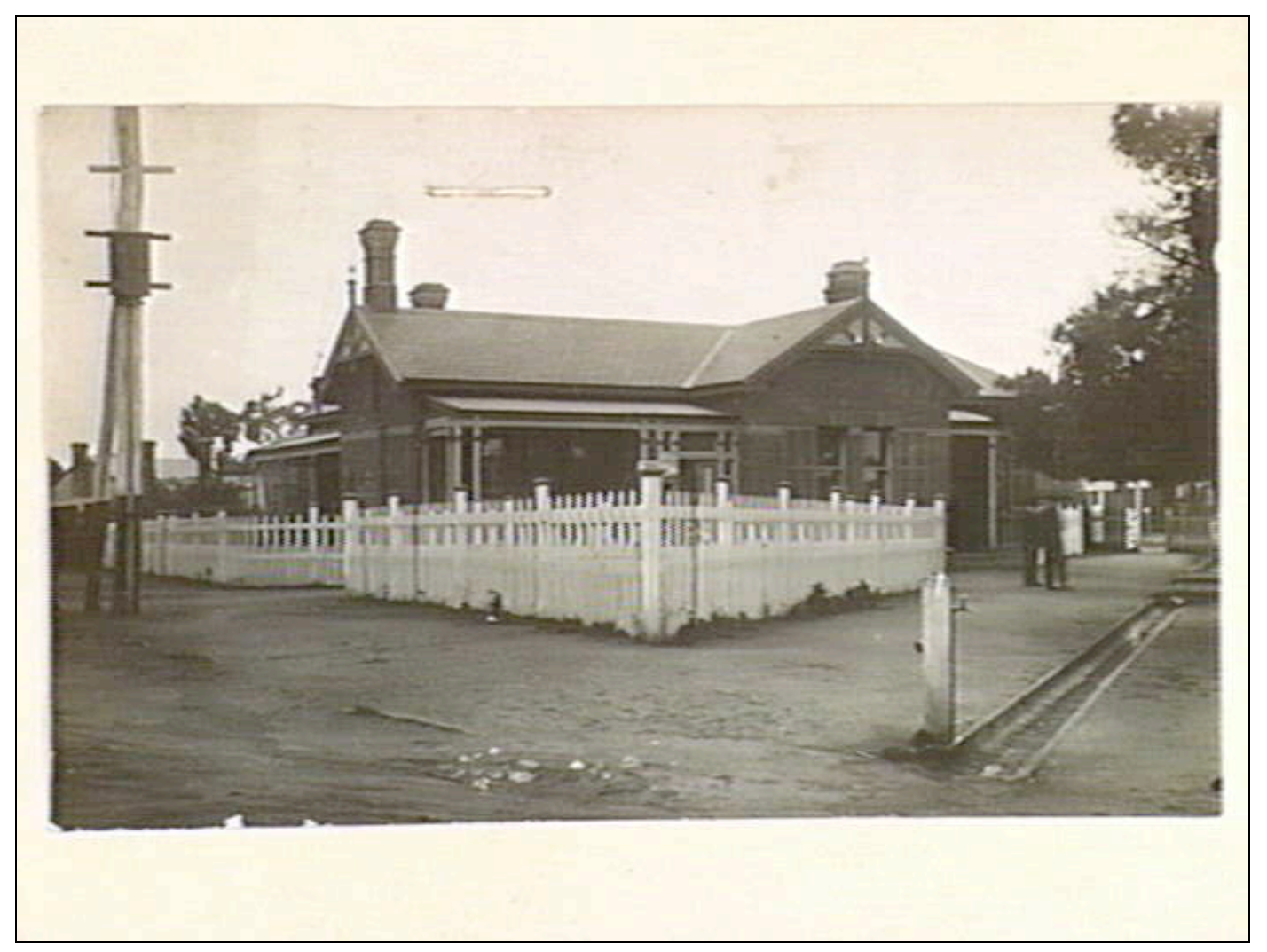

A community hub then and now: The former Rushworth Post Office now the office of the Rushworth Historical Society ${ }^{15}$

months in Rushworth, metropolitan Melbourne and other regional country centres. Because of the contractual nature of the project, selection of interviewees was based on a brief provided by the DSE. This stated that the aim of the project was to capture a history of Rushworth residents' interaction with the box and ironbark forests that surrounded them. Therefore, the first interviews were conducted with those who were most obviously connected with the forest in the eyes of the DSE - foresters who were mostly former timber workers. By recording the oral testimony of this group it was hoped that the project would capture, in the words of those who had experienced it, a way of life that had passed away.

As the project progressed the number of people interviewed expanded, with participants making suggestions and providing new directions of enquiry. The interviewing branched out to include families of foresters; farmers and graziers; environmental activists; former and present gold miners; local traders; a newspaperman; environmentalists; representatives of the Indigenous community; former prisoners-ofwar; local historians; local identities; rural finance councillors; as well as 'old timers' and 
'sylvan' people who had spent their entire adult lives working on a number of piecemeal jobs in the forest. The expansion of the interview process encouraged the authors to recognise the interconnected nature of the town, its forests and its people. While the closure of the box and ironbark forests had affected former foresters in very material ways, sections of the broader community also thought about and related to the forest that encircles them. This demonstrated the multilayered nature of the town's history.

While cultural landscapes can act as 'memorial[s] to the unknown labourer' ${ }^{17}$ such memorials are not always physically preserved through the passage of time even though they live on in the memory of those who knew them, or who had passed the knowledge of them on to their descendents. Within the oral histories it was possible to hear stories of land uses and practices that were being, or had been, erased from the physical landscape. In order to map the history of Rushworth the authors found it necessary to immerse themselves in the landscapes of the box and ironbark forests. ${ }^{18}$

Throughout the project approximately fifty interviews were recorded, representing just over five per cent of the town population. Participants' interviews were recorded using I-pods. Highly portable, easy to operate and unobtrusive, this form of technology recorded interviews in a digital format. This enabled researchers to store the data electronically or in CD-format, a simple and effective form of archiving that ensured that interviews were easily retrievable. Electronic copies were then provided to the local historical society and to the DSE. CD recordings of their interviews were also provided to each participant. This ensured that all parties had access to verbatim records of the interviews, effectively addressing theoretical concerns about the 'orality of oral sources'19 and resolving practical issues pertaining to the labour intensive and incomplete nature of transcription. $^{20}$

The authors, aware of the sensitivities about ownership of oral history, addressed this issue through providing participants with a copy of their interview. In the interests of transparency all participants were informed that the project was funded by the Victorian government and in turn all interview participants were aware of the public nature of the project. All involved were also informed of the commissioning role of the DSE. They were also informed that recordings of interviews would be kept by both the DSE and would be available to members of the public. As participation in the project was entirely voluntary, potential interviewees had the power to refuse to take part. It is therefore possible that some narratives were not recorded due to wariness on the part of potential participants. Sponsored projects are potential sites of conflict of interest, as James B. Lane amongst others has argued. ${ }^{21}$ It must be acknowledged, however, that without sponsorship, the Rushworth Oral History Project would not have eventuated and the opportunity to record the oral history of the community would have been lost. ${ }^{22}$

The tale of Bill Almaca from Tatura, of whom Ron Risstrom informed us, was a case in point. ${ }^{23}$ Bill had been an internee at Camp 13, a Second World War POW camp. His 
story, as Mr Risstrom briefly told it, captured the researchers' imagination as part of a local history that had been largely forgotten, or rarely discussed. For the researchers, the story of Bill's internment added another layer to what was increasingly being viewed as an 'archaeological' survey of Rushworth's history, a history comprised of many layers which could be revealed through a combination of oral history and cultural landscape analyses. However, when Bill was eventually located - through Arthur Knee at the Tatura Museum - it became evident that he had reached an age where he was no longer able to participate in an interview. This galling incident is indicative of one of the major problems that confront oral historians. Simultaneously the reason for collecting and recording oral testimony and one of the most frustrating aspects of the discipline, the limited lifespan of oral sources encouraged the researchers to recognise that oral history has its limitations as well as its uses.

Oral history, by its very nature, is an active process, ${ }^{24}$ created through the intervention of historians who 'record' the oral testimony. ${ }^{25}$ It is an historical record often shaped by the gate keeping of historians, sponsors and participants. In the Rushworth Oral History Project, the DSE determined the general scope of the project and its aims, while the historians chose whom to record. During the interview itself the historian acted as a listener, co-producing ${ }^{26}$ a 'dialogue between respondent and interviewer'. ${ }^{27}$ At various stages during the process the interviewers could direct the conversation, interject, inhibit the interviewee through their very presence or even encourage the respondent to use their thoughts or phrases, replacing the interviewer's words with their own. More positively they could also encourage, smile and intelligently question the interviewee, eliciting 'more lively and extended storytelling'. ${ }^{28}$ In return participants could edit their conversation 'on record', ${ }^{29}$ redirect the interview in a direction more to their personal taste and simultaneously provide a wealth of information on their thoughts about and feelings for the forests surrounding Rushworth. It was in fact the collaborative nature of oral history that allowed the authors to obtain the data they required to map the history that had created both Rushworth's landscape and its identity.

\section{MAPPING HISTORICAL LANDSCAPES}

The differing, and sometimes antagonistic, understandings that the locals had of the forest revealed common threads connecting the people of Rushworth to their surrounding forests. In order to map these ontological landscapes participants were asked to identify 'special places' within the forest as part of their interview. The heuristic device of 'special places' was then used as an historical tool in a number of ways. Firstly it became a device that could trace 'grand abstractions... to the local, the specific, the situated', ${ }^{30}$ helping the authors to place the local history of the town within the context of broader historical narratives. It was also used to ground the history of Rushworth within the physical landscape of the region. Helen Verran has described such techniques as a 
'translation mechanism of micro worlds... [that] features forms of interrogation, naming and tracking,. ${ }^{31}$ The intimate intermingling of many of the stories went a long way towards underscoring the importance of considering all of the cultural landscapes evoked during the interviews, which were linked through both proximity and time to one another.

Before examining these interconnected narratives of time and place, it is appropriate to acknowledge the place of 'deep history'. ${ }^{32}$ In what is primarily a history of postEuropean settlement Victoria, it is important to highlight the problematic position of both ancient and current Indigenous stories. Such stories are problematic because within the colonial narrative 'the attempted dispossession of Indigenous people is at times conveniently forgotten while at other moments colonial violence is accepted and excused through a trope that celebrates "manifest destiny and triumphalism"'. ${ }^{33}$ Although some of the narratives, or archaeological layers of history, touch upon the rather brutal history of European contact with the Indigenous population, details of these episodes were conspicuously absent from most interviews.

Brien Nelson, a Djarradjarrawurrung elder, recalled as a child moving with his family to Rushworth to cut wood as a means of income and keeping the family together having moved down from the Barmah Lakes. He commented that his extended family formed a team and seasonally cut wood 'for the Mooroopna hospital, butter factories and so on who needed steam to drive the machinery'. ${ }^{34}$ It is thus intended that this article might partially articulate the historical landscapes that deep historical narratives can later critique. That is, the authors retain an awareness of the artificiality of placing postsettlement narratives at the crux of the project's story. ${ }^{35}$

Interviews did, however, reveal many vibrant narratives which illustrated the occasionally conflicting attitudes inhabitants had towards the forests surrounding them and the ways in which they used this landscape to construct their identity as a forestry and historic gold mining town. Amongst some of the foresters who were interviewed there was an understandable resentment at the closing of the forests to logging. Despite government financial packages to forcibly expel the timber industry, many of them were disgruntled at the passing of their way of life. ${ }^{36}$ It was also deeply felt among some that it was a decision imposed on the community from outside and, for whatever reasons, their loss had not attracted the public attention that other forest closures had in Victoria. This raised the 'provincialism problem,' ${ }^{37}$ where recognition of issues is reliant on proximity to city centres. Foresters expressed concerns about the health of the forests, arguing that since their closure forests had become significantly 'untidy' and that the build-up of flammable material could cause untold damage to the forest were a bushfire to occur. These interviewees expressed a feeling that their unique style of forest management, representing the knowledge of successive generations of sylvan people, had not been given its due weight in recent times. ${ }^{38}$ 
The above description of a particular historical landscape was not a universal understanding and other foresters and pastoralists seemed to be in agreement with the new direction of the parks, in particular, what they described as the halting of unsustainable logging practices. Of some note was the fact that not all of these particular interviewees wished to express such opinions during the interview and only discussed them after the audio equipment had stopped recording. ${ }^{39}$ As mentioned during the discussion of the methodology, participants in conjunction with the DSE and the authors had the ability to create an oral record that suited their purposes or desires. What became apparent, therefore, as the interview process progressed, was that a community of residents felt that the importance of recording a proud history of the town's forest industries outweighed other considerations. It also reflected the artificial nature of oral history in general and the ways in which this artificiality could be used in an attempt to control the identity of the town. ${ }^{40}$

Other interviewees were more forward in their support of the closing of the forest. Local environmental campaigners saw the new park as an opportunity to introduce visitors to the many secrets of the forest, ${ }^{41}$ which the locals had been enjoying for years. These included, for example, the cover of wildflowers dotted in groups throughout the forests. ${ }^{42}$ When we recorded Socrates Hedditch another layer was uncovered as the activities of this local identity and environmental activist demonstrated a very different relationship with the forest from that spoken about by old miners and loggers. This was highlighted by his observation that despite living with his wife in the town for twenty-one years 'artists are not that popular in Rushworth, it is a woodcutting town... so we have felt quite isolated up to a point'. ${ }^{44}$ These promoters of the arts and eco-tourism formed a contrasting layer of interaction between residents and their cultural and historical landscape.

Historical as well as more current interactions with the landscape were also revealed during interviews. In fact, what many of the interviews documented was the staggering diversity of people who retained a strong link to the past - whether personal, institutional or community based. This interest in the history of Victoria, particularly its settlement and gold rush periods, was emphasised by a visit to the Rushworth Museum to interview Lorrain Rule. As well as acting as a vast repository of material culture, the museum has slowly built up genealogical records of the area. Lorrain Rule told us how people had travelled from as far away as New Zealand and Canada to specifically visit Rushworth and experience where their ancestors had once lived. ${ }^{45}$

This search for stories of past families in the town was another historical layer that emerged during the fieldwork. Mrs Rule informed us that this was one of the primary functions of the Rushworth Museum, although such stories were often buried and took some time to uncover. She also commented that she had visited the area many times before settling in Rushworth, as the Warranga Basin had been a holiday spot for her 
family. After establishing herself in the town she was delighted to discover that, unbeknownst to her, some of her own family had joined in the initial gold rushes in the surrounding forest. ${ }^{46}$ The stories of this part of her family were forgotten for many years, as her ancestors' presence at the gold rush had been brief, cut short by an influenza epidemic. $^{47}$

The history of gold in the region was obviously of vital importance to an understanding of the numerous layers of historical landscapes that accumulated after settlement. Originally staked out as a gold rush town, the landscape of Rushworth remained indelibly imprinted with these narratives. During one of the interviews a current miner, Don Rutherford, showed us an original miner's right that he claimed related to the mine he still operates just outside of the town. He described in some detail the peculiarities of working with a miner's right from 1861. These included the provision that on a one hundred square metres claim the miner must work for at least eight hours a fortnight to retain title. ${ }^{48}$ An investigation may question the historical accuracy of his claim as it related to his particular piece of land, and later legal history may have subsumed the importance of retaining the actual physical piece of paper of the miner's right. ${ }^{49}$ Yet any such inaccuracies would miss the vital importance that this miner's right had for Rutherford's narrative and its ability to lead us to a particular layer of the region's history. ${ }^{50}$ There were other stories of the gold rush period, relating how ancestors of the interviewees had crossed the landscape to find gold, or to undertake the lucrative supply of the miner's needs. In fact one of the interviewees relayed a story from his father who, as a butcher, used to take meat out to the miners at Whroo. This butcher would travel along the Tait-Hamilton Road with a dray full of fresh meat that was only kept refrigerated by a wet hessian cloth. ${ }^{51}$

The purpose of conducting the oral history interviews had been to draw out the stories of the community: to engage with them in an uncovering of past historical landscapes. Within these stories the concept of the forest as a resource for humans, whether for gold, wood or eco-tourism, was powerfully expressed. ${ }^{52}$ At the Balaclava mine site, however, Doris King spoke of a firsthand connection with actions against the Aborigines in the nineteenth century. ${ }^{53}$ Thus a layer of understanding which had been missing from so many of the interviews was finally uncovered. This allowed the authors to map out a little known layer in Rushworth's history which had been omitted from its public identity as a forestry and gold mining town.

European contact with Indigenous people was not the only history that had been missing from the ontological landscape. In recording Mr Herman Ortmann's testimony the authors were able to include the mixed history of prisoner of war camps, which was absent in other interviews. Mr Ortmann, Wehrmacht naval officer on the Kormoran (HSK 


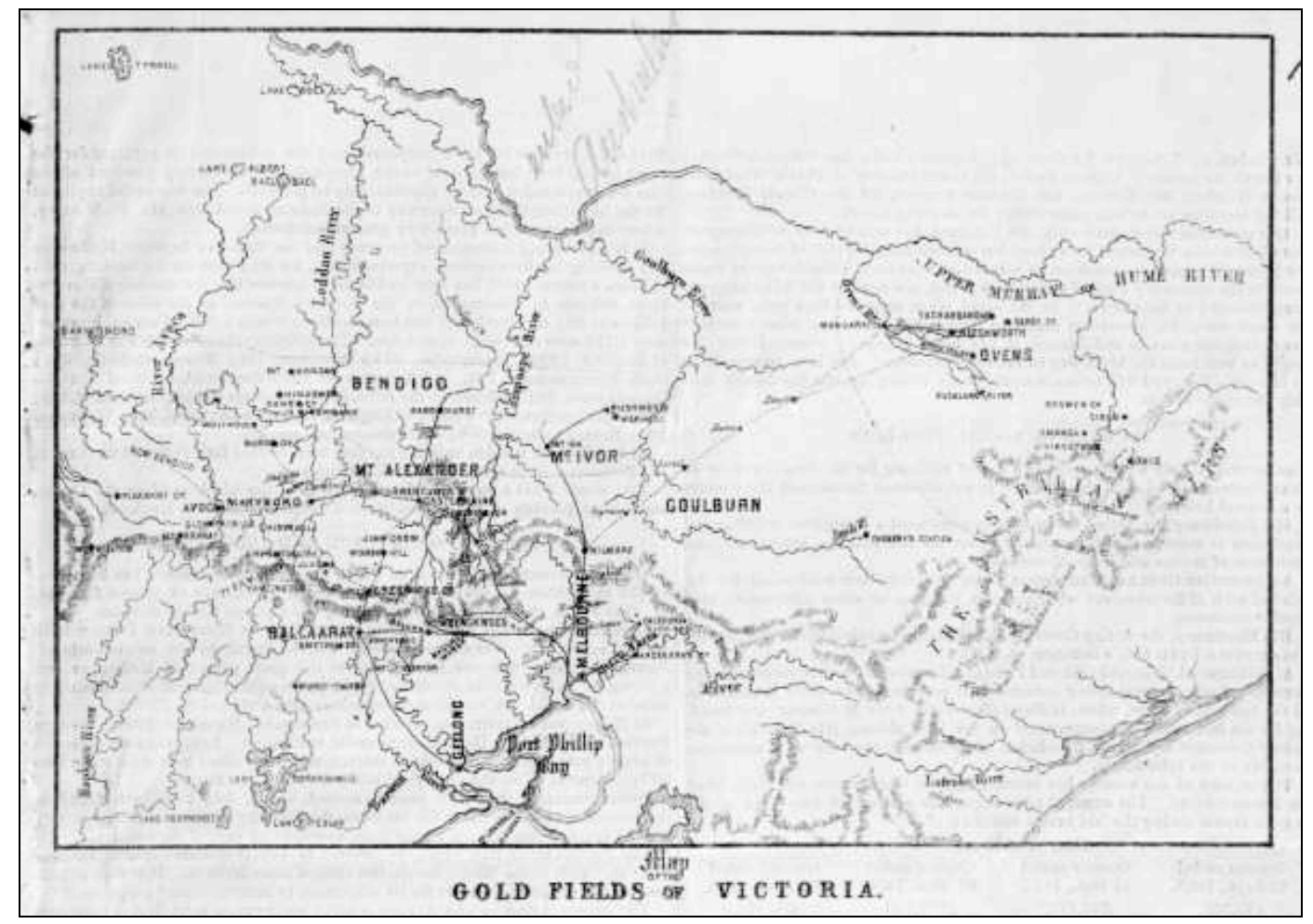

Traversing the Roads of Gold: Map of the Goldfields of Victoria $1856^{54}$

8) had been held during the Second World War at the Graytown Camp and recalls that he spent time in the forest 'cutting wood for the Australian Army... where every man had to cut two tons of wood that and then he could go'. ${ }^{57}$ This task 'would take between four and six hours'. His oral history provides a wealth of detail about daily life in the camp, containing a poignant description of a young German celebrating his twenty-first birthday in the central Victorian box and ironbark forest and the interaction of the internees with the Australian guards. ${ }^{58}$ Moreover, his post-war experiences also tie into other broader landscapes such as his return to Germany and subsequent migration back to Australia. ${ }^{59}$ Unfortunately such disclosures were rare and throughout the majority of interviews the authors were often only able to hear echoes of such historical landscapes. ${ }^{60}$

The State Government's designation of the various forests surrounding the town as parkland led to the passing of the timber industry. ${ }^{61}$ Yet, as the interviews showed, there is a desire on the part of the local community to preserve the memories, lifestyles and community organisation of an era that still defines the identity of the local residents. The vibrancy of this desire was also expressed in the tension of some interviewees between what they would say during the recorded interviews and what they would express off the record. 
By adopting an inclusive and deliberately open consultation process investigators gathered a diverse range of historical stories and opinions about the forest legacy in Rushworth and the surrounding region. Thus, while the focus of the investigation explicitly aimed to redress community concerns about fading memories of the timber industry and its allied legacies throughout the region, the Rushworth Oral History Project also became a site where differing and occasionally conflicting experiences could legitimately be included as important parts of a complex and multi-layered historical landscape. ${ }^{62}$

The Rushworth Oral History Project began with the authors having little or no association with the forests of Rushworth. Nonetheless we now feel that we have been afforded an insight that is quite personal. During the first drive up to Rushworth barely any notice was taken of the forest and landscape as we drove from Whroo to Rushworth. Yet, when we last left and saw a stand of 'tall-boys' on the Tait-Hamilton Road the significance of a particular historical landscape was evoked. It was through the privilege of the locals' own understanding of the forest and its 'special places' that we could see more than just another stand of trees. The concept of historical landscapes reflects how the pastoral, mining, industrial and forestry histories have taken place and been shaped by the physical landscape of the region. These narratives were understood as historical landscapes that could be mapped onto the current physical landscape of the region, providing hints of previously existing landscapes. By concentrating on the dual themes of oral history and the landscapes in and around Rushworth, the authors were able to consider community history in the context of local places of significance and to culturally map the fractious and enduring Rushworth community up to the present day.

\section{ENDNOTES}

\footnotetext{
${ }^{1}$ When using the term cultural landscapes we refer to the remnants of the built environments created as a consequence of gold discoveries together with the collateral visual, oral and documentary material that assists in the interpretation of these environments. Keir Reeves wishes to thank Councillor Marion Riley for her support of this project and Ann Dillon for her research assistance.

2 Joseph Anthony Amato, Rethinking Home: A Case for Writing Local History, Berkeley, University of California Press, 2002, p4.

${ }^{3}$ Cultural Heritage Unit, Rushworth Oral History Project, Bendigo Department of Sustainability and Environment, 2006.

${ }^{4}$ For the manner in which the construction of memory can be used to fit modern needs see Paul Thompson, The Voice of the Past: Oral History, Oxford, Oxford University Press, $3^{\text {rd }}$ ed, 2000, p125.

${ }^{5}$ Thus, the commissioning process reflected the importance of 'engaging the community as a central component in any synthesis of the [remains of the] historical record'. Alexander Trapeznik and Gavin McLean, 'Public history, heritage, and place', in Alexander Trapeznik (ed), Common ground: heritage and public places in New Zealand, Dunedin, University of Otago Press, 2000, pp14-23; 14.

6 ibid, p14.

7 David N. Livingston, 'Science and Religion: Forward to the Historical Geography of an Encounter', Journal of Historical Geography, vol 20, no 4, 1994, p368.

${ }^{8}$ Some of the reasons leading to the establishment of various National and State Parks throughout the box and ironbark region can be found in Environment Conservation Council (ECC), 'Box Ironbark Forests and Woodlands Investigation: Resources and Issues Report', ECC, Melbourne, 1997, p1.
} 
${ }^{9}$ Carolyn Slijkerman, Heathcote and Rushworth State Forests, Bendigo, Department of Sustainability and Environment, 2003, p3.

${ }^{10}$ Chris McConville, 'Reading a landscape', in Graeme Davison and Chris McConville (eds), A Heritage Handbook, Sydney, Allen \& Unwin, 1991, pp227-35; 228.

11 'A Gold Mine Shaft, Rushworth 1923', Accession number H28738, Third Reso Train tour to agricultural districts of northern Victoria, State Library of Victoria.

${ }^{12}$ Chris McConville, 'Reading a landscape', in Graeme Davison and Chris McConville (eds), A Heritage Handbook, Sydney, Allen \& Unwin, 1991, pp227-235, 228.

13 ibid, p233.

${ }^{14}$ Donald Ritchie, Doing Oral History: A Practical Guide, New York, Oxford University Press, 2003, p45.

15 'Rushworth Post Office', Accession number H89.105/204, Post offices in Victoria, 1917-1930, State Library of Victoria.

${ }^{16}$ Donald Ritchie, Doing Oral History: A Practical Guide. Second Edition, New York, Oxford University Press, 2003, p45.

${ }_{17}$ Peter Fowler, Landscapes for the World: Conserving a Global Heritage, Bollington, Windgatherer Press, 2004, p31.

${ }^{18}$ For an analysis of the varying roles of public and people's history in the Australian context see Graeme Davison, 'Paradigms of Public History', Australian Historical Studies, vol 24, no 96, April 1991, pp4-15.

${ }^{19}$ Alessandro Portelli, The Death of Luigi Tratsulli and Other Stories: Form and Meaning in Oral History, Albany, State University of New York Press, 1991, p48.

${ }^{20}$ ibid, p47.

21 James B. Lane, 'Oral History and Industrial Museums', The Journal of American History, vol 80, no 2, September 1993, p614. See also Daniel J. Walkowitz, 'Corporate History, or Giving History the Business', in Susan Potter Benson, Stephen Brier, and Roy Rosenzweig (eds), Presenting the Past: Essays on History and the Public, Philadelphia, 1986, pp225-36.

${ }^{22}$ Some of the locals of Rushworth understood this important aspect of the project and would often lament that a certain person had recently passed away as they had been a great source of local stories.

${ }^{23}$ Ron and Wes Risstrom interview, Rushworth, 25 August 2005. See Cultural Heritage Unit, Rushworth Oral History Project, 2005, pp21-22.

${ }^{24}$ Ronald J. Grele, 'Private Memories: Public Presentation: The Art of Oral History', Ronald J, Grele (ed), Envelopes of Sound: The Art of Oral History, $2^{\text {nd }}$ edition, Precedent Publishing, Chicago, 1985, pp246-7.

25 'An interview becomes history only when it has been recorded, processed in some way, made available in an archive, library or other repository, or reproduced in a relatively verbatim form for publication.' Ritchie, Doing Oral History, p24.

${ }^{26}$ Martin Kohli, 'Biography: Account, Text, Method', in Biography and Society in Charles T. Morrissey, 'Riding a Mule Through The "Terminological Jungle": Oral History and the Problems of Nomenclature', Oral History Review, vol 12, 1984, p22.

27 James Bonar, Roger Simon and Michael P. Weber, Lives of Their Own: Blacks, Italians, and Poles in Pittsburgh, 1900-1960, University of Illinois Press, Urbana, 1982, p270.

${ }^{28}$ Anna Green, 'Returning History to the Community: Oral History in a Museum Setting', Oral History Review, vol 24, no 2, Winter 1997, p64.

${ }^{29}$ The identities of the interviewees who made 'off the record' comments were not noted in either the recordings or the attendant reports supplied to the DSE. For some discussion of the ethical issues raised by 'off the record' comments see Katherine Borland, 'That's Not What I Said": Interpretative Conflict in Oral Narrative Research', in S. B. Gluck and D. Patai (eds), Women's Words: The Feminist Practice of Oral History, Routledge, London, 1991, pp63-75; Kathleen Blee, 'Evidence, Empathy and Ethics: Lessons From the Oral History Klan', Journal of American History, vol 80, no 2, 1993, pp596-606.

${ }^{30}$ David N. Livingston, 'Science and Religion', pp368-9.

${ }^{31}$ Helen Verran, 'A Postcolonial Moment in Science Studies: Alternative Firing Regimes of Environmental Scientist and Aboriginal Landowners', Social Studies of Science, vol 32, nos 5-6, 2002, pp751-2. Emphasis added.

${ }^{32}$ Tony Birch, '"Death is forgotten in Victory": Colonial Landscapes and Narratives of Emptiness', in Jane Lydon and Tracey Ireland (eds), Object Lessons Archaeology and Heritage in Australia, Text Publishing, Melbourne, 2005, pp186.

33 ibid, p187.

34 'Brien Nelson interview', Bendigo, 14 June 2005. See Cultural Heritage Unit, Rushworth Oral History Project, pp18-19.

${ }^{35}$ Chris McAuliffe, 'Let's Talk About Art: Art and Punk in Melbourne', Art and Australia, vol 34, no 4, Spring 1997, pp502-12.

${ }^{36}$ Cultural Heritage Unit, Rushworth Oral History Project, pp30; 33.

${ }^{37}$ Terry Smith, 'The Provinicialism Problem', Artforum, vol 13, no 1, September 1974, pp54-9. 
${ }^{38}$ Ron Risstrom interview, Rushworth, 25 August 2005. See Cultural Heritage Unit, Rushworth Oral History Project, pp21-2.

${ }^{39}$ For a discussion of the bias that the interviewer and interviewee can introduce to the 'historical record' of oral history see Thomson, op cit, pp33-43.

${ }^{40}$ Recognising this is to recognise the self-reflectivity of the practice of the oral and public history. Rebecca Conrad, 'Facepaint history in the season of introspection', The Public Historian, vol 25, no 4, Fall 2003, pp10-11.

${ }^{41}$ For example, tourism was discussed as one of the more recent layers of historical landscapes during the interviews. Socrates Hedditch interview, Rushworth, 6 September 2005. See Cultural Heritage Unit, Rushworth Oral History Project, p12.

${ }^{42}$ Neville Rogerson interview, Rushworth, 25 August 2005. See Cultural Heritage Unit, Rushworth Oral History Project, p24.

${ }^{43}$ Socrates Hedditch, a local artist, had been heavily involved in the campaign for a National Park.

${ }^{44}$ Socrates Hedditch, a local artist, had been heavily involved in the campaign for a National Park.

${ }^{45}$ Lorrain Rule interview, Rushworth, 16 December 2005. See Cultural Heritage Unit, Rushworth Oral History Project, p24.

46 ibid.

${ }^{47}$ ibid.

${ }^{48}$ Don Rutherford interview, Rushworth, 6 September 2005. See Cultural Heritage Unit, Rushworth Oral History Project, p27.

${ }^{49}$ B. Edgeworth, C. J. Rossiter and M. A. Stone (eds), Sackville and Neave: Property Law, Lexis Nexis Butterworths, Chatswood NSW, 2004, pp454-57.

${ }^{50}$ ibid.

${ }^{51}$ Bob Barlow interview, Rushworth, 16 December 2005. See Cultural Heritage Unit, Rushworth Oral History Project, p6.

${ }^{52}$ See, for example, Graeme Aplin, Heritage: Identification, Conservation and Management, Oxford University Press, Melbourne, 2002, pp49-66.

${ }_{53}$ Doris King interview, Whroo, 25 August 2005. See Cultural Heritage Unit, Rushworth Oral History Project, p15.

54 'Map of the goldfields of Victoria 1856', Accession number NLA00/08/56/1, Illustrated newspaper file: The Newsletter of Australasia, State Library of Victoria.

${ }^{55}$ See, for example, Graeme Aplin, Heritage: Identification, Conservation and Management, Oxford University Press, Melbourne, 2002, pp49-66.

56 'Doris King interview', Whroo, 25 August 2005. See Cultural Heritage Unit, Rushworth Oral History Project, p15.

${ }^{57}$ Hermann Ortmann interview, Upper Ferntree Gully, 14 September 2005.

${ }^{58}$ ibid. See also Cultural Heritage Unit, Rushworth Oral History Project, pp18-19.

${ }^{59}$ ibid.

${ }^{60}$ On the construction of texts see, for example, Steven Shapin and Simon Schaffer, The Leviathan and the Air Pump: Hobbes, Boyle, and the Experimental life, Princeton University Press, Princeton, 1985, pp60-5.

${ }^{61}$ See, for example, ECC.

${ }^{62}$ As to the tension between a living history and nostalgia, see Graeme Davison, The Use and Abuse of Australian History, Allen \& Unwin, Sydney, 2000, pp163-65. 